\title{
ОСОБЛИВОСТІ РОЗВИТКУ ЗАПАЛЬНИХ РЕАКЦІЙ У КІРКОВИХ ТА ПІДКІРКОВИХ ВІДДІЛАХ ГОЛОВНОГО МОЗКУ ЩУРІВ ПІСЛЯ ЛЕГКОЇ ЧЕРЕПНО-МОЗКОВОЇ ТРАВМИ
}

\author{
ОМ. І. Лісяний, А. В. Паламарьова, А. О. Лісяний \\ ДУ «Інститут нейрохірургії НАМнУ імені академіка А. П. Ромоданова», Київ
}

РЕЗЮмЕ. Черепно-мозкова травма (ЧМТ) характеризується цілим рядом патологічних реакцій у паренхімі мозку, які залежать від тяжкості травми і мають довготривалий перебіг, що може призводити до розвитку неврологічних порушень та інвалідності, серед яких важливу роль відіграють запальні процеси, які реалізуються як мікрогліальними та гліально-макрофагальними клітинами головного мозку, так і з допомогою нейтрофілів, моноцитів та лімфоцитів крові. У той же час ще недостатньо вивчений розвиток цих патологічних імунозапальних реакцій в окремих важливих структурах головного мозку.

Мета - вивчення особливостей стану запалення на 5-ту добу після легкої чМТ у щурів, а саме визначення кількості та активності прозапальних клітин і рівня набряку в кірковій, гіпокампальній і таламічній ділянках мозку.

Матеріал і методи. В роботі використані експериментальні тварини - аутбредні статевозрілі щури різної статі вагою 120-160 г (розведення віварію дУ «ІНХ НАМН»). Усі роботи з експериментальними тваринами проводили з дотриманням законодавчих норм та вимог Закону України № 3447 IV «Про захист тварин від жорстокого поводження", "Європейської конвенції про захист хребетних тварин, які використовуються для дослідних та інших наукових цілей» (Страсбург, 1986), з урахуванням принципів біоетики та норм біологічної безпеки. Тварин утримували у стандартних умовах акредитованого віварію, евтаназію проводили під ефірним наркозом. Черепномозкову травму в щурів моделювали згідно з рекомендаціями Романова Г. А. та ін. (2015) шляхом скидання вантажу (масою 100 г) з висоти 120 см на голову наркотизованих щурів. Отримання клітин головного мозку щурів із певних часток мозку проводили методом ферментної дисоціації 0,4 \% розчином трипсину. Оксид азоту визначали за допомогою реактиву Грісса. Набряк певних структур мозку визначали за вмістом води в тканині мозку до і після 48-годинного висушування.

Результати. Після легкої ЧМТ у щурів виникають запальні реакції в кіркових та підкіркових ділянках головного мозку, які проявляються на 5-ту добу після травми збільшенням кількості прозапальних клітин у досліджуваних частках мозку, підвищеною продукцією оксиду азоту та розвитком набряку мозку. В гіпокампальній і таламічній ділянках мозку прояви запалення значно більші, ніж у кіркових структурах головного мозку.

Висновок. Прояви запалення на 5-ту добу після легкої ЧМТ у різних ділянках мозку вказують на те, що ця травма супроводжується значними порушеннями, які потребують проведення відповідного лікування.

ключові СловА: черепно-мозкова травма; щури; запалення; набряк мозку; оксид азоту.

Вступ. Відомо, що черепно-мозкова травма (ЧМТ) характеризується цілим рядом патологічних реакцій у паренхімі мозку, які залежать від тяжкості травми і мають тривалий, іноді прогресуючий перебіг, що може призводити до розвитку неврологічних порушень та інвалідності, серед яких важливу роль відіграють запальні процеси [1-3]. Ці реакції мають багатоетапний механізм розвитку і реалізуються як мікрогліальними і гліально-макрофагальними клітинами головного мозку, так і за допомогою прозапальних клітин крові, а саме нейтрофілів, моноцитів та лімфоцитів $[1,4]$. Динаміка розвитку запальних реакцій після ЧМТ вивчена досить детально. Вона характеризується продукцією прозапальних цитокінів, активних форм оксидів кисню та азоту, активацією фагоцитарних та цитотоксичних імунних клітин мозку та крові, розвитком вторинного набряку мозку, які відмічаються впродовж тривалого терміну після травми [5-7]. Водночас ще недостатньо вивчено розвиток цих патологічних імунозапальних реакцій в окремих важливих структурах головного мозку, наприклад, таких як кір- кова, гіпокампальна та таламічна ділянки мозку $[8,9]$.

Мета - вивчення особливостей стану запалення на 5-ту добу після легкої ЧМТ у щурів, а саме визначення кількості, активності прозапальних клітин і рівня набряку в указаних ділянках головного мозку.

Матеріал і методи дослідження. В роботі використані експериментальні тварини - 48 щурів, різної статі вагою 120-160 г (розведення віварію ДУ «IHX НАМН»). Усі роботи з експериментальними тваринами проводили з дотриманням законодавчих норм та вимог Закону України № 3447 IV «Про захист тварин від жорстокого поводження», «Європейської конвенції про захист хребетних тварин, які використовуються для дослідних та інших наукових цілей» (Страсбург, 1986), з урахуванням принципів біоетики та норм біологічної безпеки. Тварин утримували у стандартних умовах акредитованого віварію, евтаназію проводили під ефірним наркозом.

Моделювання ЧМТ у експериментальних щурів. Черепно-мозкову травму в щурів моделювали 
Огляди літератури, оригінальні дослідження, погляд на проблему, випадок з практики, короткі повідомлення згідно з рекомендаціями Романова Г. А. та ін. (2015) шляхом падіння вантажу (масою 100 г) з висоти 120 см на голову щурів, що були занаркотизовані внутрішньочеревно 0,5 мл суміші кетаміну 70,0 мг/кг та седазину 15 мг/кг і перебували в стані наркотичного сну, який тривав до 30 хв. Голову тварин розташовували під пластиковою вертикальною трубою діаметром 2,5 см і висотою 120 см таким чином, щоб удар (контакт) вантажу, що падає, припадав на ліву півкулю в ділянці тім'яної та потиличної часток головного мозку. Після отримання травми у тварин рефлекторно відбувалась затримка дихання, а у деяких були судоми та підняття вверх хвоста на кілька секунд, але потім дихання відновлювалось до звичайного ритму. Судом та інших порушень або виділення сечі та калу у тварин не було. Через 20-30 хв тварини виходили із наркозу і починали прокидатися та рухатися по клітці.

Методика отримання окремих структур головного мозку у щурів. Виділення певних ділянок головного мозку, де розташовані гіпокамп, таламус, мозочок чи кора, проводилось з урахування анатомії мозку щурів та топографічного опису їх локалізації в атласах та рекомендаціях $[11,12]$. Кору виділяли з лобно-скроневої частки мозку шляхом вирізання лезом бритви ділянки кори товщиною 2-3 мм та довжиною до 8-10 мм. Після видалення кіркового шару мозку на відстані 3-5 мм від брегми виділяли підкіркову зону мозку розміром $5 \times 5 \times 3$ мм, де, згідно з анатомією мозку щурів розташований гіпокамп [12]. Таламічногіпоталамічна ділянка, яка розташована в нижніх відділах півкуль мозку, у ділянці стовбура мозку. Для дослідження забирали кусочки тканини мозку розміром $5 \times 5 \times 5$ мм. Безумовно, виділити в чистому вигляді лише гіпокамп чи таламус із мозку щурів практично дуже складно, майже неможливо, але ділянки їх розташування разом із білою речовиною, яка їх оточує, і де розвиваються запальні реакції, досить легко можна отримати, тому ми вважаємо, що правильно говорити про ділянки, де локалізовані певні структури головного мозку. Мозочок легко відділявся від півкуль мозку і його фрагмент розміром 4-5 мм забирали для досліджень. Вагу відібраних фрагментів мозку визначали на торсійних вагах, у більшості випадків вона складала 110-150 мг.

Методика отримання клітин головного мозку щурів методом ферментної дисоціації.

Відібрані для досліджень фрагменти певних ділянок головного мозку після зважування подрібнювали маленькими ножицями в 10,0 мл пробірці та заливали 1,0 мл 0,4 \% розчину трипсину на середовищі Хенкса і поміщали в термостат при $37{ }^{\circ} \mathrm{C}$ на 1 год. Періодично, через 15-20 хв,

пробірки легенько перемішували. Після інкубації в термостаті отримані суспензії фільтрували через капроновий фільтр та два рази центифугували при 1000 об/хв по 5-7 хвилин. Осад клітин ресуспезували в 2,0 мл 199 середовища і підраховували кількість клітин стандартним методом із $3 \%$ оцтовою кислотою в камері Горяєва. Життездатність клітин визначали з 0,1 \% розчином трипанового синього, вона складала більше 80 \% у більшості випадків. Отримані суспензії клітин за допомогою 199 середовища доводили до $10 \times 10^{6}$ клітин в 1,0 мл і використовували в подальших дослідах.

Методика визначення набряку мозку. Визначення набряку певних структур мозку проводили за вмістом води у тканині мозку до і після висушування при $60{ }^{\circ} \mathrm{C}$ впродовж 48 годин у термостаті за методом Khau M et al. 2009. Методика полягала в наступному: приблизно одного розміру фрагменти різних структур головного мозку поміщали на целофан або тонкий папір розміром 10×10 мм з вагою менше 2,0 мг та зважували на електронних вагах і поміщали в термостат при $60{ }^{\circ} \mathrm{C}$ на 48 годин. Після висушування прилиплі до паперу залишки мозку повторно зважували і визначали відсоток води за формулою \% води = (вага до висушування - вага після висушування) : вага до висушування $\times 100$ (Khau M et al., 2009).

Визначення продукції оксиду азоту (NO) клітинами головного мозку. Відомо, що оксид азоту разом з супероксидними сполуками кисню $є$ постійними компонентами різних форм запалення та патології. За визначенням вмісту та продукції NO можна судити про тяжкість та особливості перебігу запалення, в тому числі й ЦНС. Визначення рівня продукції NO проводили за методом, який описаний Кіселиком І. О. та ін. (2001) з використанням реактиву Грісса [14]. Методика полягала в наступному: 1,0 мл суспензії в дозі $10 \times 10^{6}$ клітин, які були виділені з різних фрагментів мозку шляхом ферментної дисоціації розчином трипсину, інкубували 1 годину в термостаті, для продукції ними NO, потім суспензію центрифугували при 3000 об/хв впродовж 10 хвилин. Супернатанти клітин після центрифугування переносили В окремі пробірки і до 500 мкл кожного супернатанту додавали 500 мкл 5 \% оцтової кислоти та 1,0 мл реактиву Грісса. Після 30-хвилинної інкубації визначали показники на СФ при 450 нм проти $\mathrm{H}_{2} \mathrm{O}$ в контролі. Кількість $\mathrm{NO}$ визначали за стандартною кривою в мкг на $10 \times 10^{6}$ клітин, взятих у реакцію.

Статистичний аналіз отриманих у результаті дослідження даних проводили з використанням пакета статистичних програм «Statistica 8.0», програмне забезпечення StatSoft, Inc. (2007). Дані представлено у вигляді $(\mathrm{M} \pm \mathrm{m})$, де $\mathrm{M}$ - середнє 
Огляди літератури, оригінальні дослідження, погляд на проблему, випадок з практики, короткі повідомлення значення; m - стандартне відхилення від середнього значення; d - середнє квадратичне відхилення від середнього значення; а також у вигляді М (25\%; 75 \%), де М - медіана, (25\%; 75 \%) - інтерквартильний інтервал між 25-м і 75-м процентилями. Статистично значущими вважали відмінності при р<0,05, статистично високозначущими при $\mathrm{p}<0,01$.

Результати й обговорення. Дослідження вмісту клітин, які виділяли при ферментній дисоціації різних структур мозку тварин з ЧМТ, виявило, що в таламусі та гіпокампі була найбільша кількість клітин у перерахунку на 10 мг ваги певного фрагмента (табл. 1), тоді як з кіркових ділянок лобної та скроневої часток мозку виділялось дещо менше клітин, вірогідної різниці з відповідними ділянками інтактних тварин не виявлено

$(p=0,062) .3$ мозочка тварин із ЧМТ та інтактних контрольних щурів виділялась приблизно однакова кількість клітин. Потрібно зазначити, що у здорових щурів (контрольна група) із різних ділянок головного мозку виділяли приблизно однакову кількість клітин, що складало 3,6-4,1×107 клітин на 10,0 мг тканини мозку, а це може свідчити про те, що коли запалення в мозку немає, то в його паренхімі міститься стабільна кількість клітин, які належать до клітин мікрогліального ряду, хоча морфологічні дослідження свідчать про різну кількість мікрогліальних клітин у певних структурах мозку $[2,7]$. Збільшення кількості клітин після ЧМТ може свідчити як про перерозподіл мікрогліальних клітин у тканині мозку, так і про інфільтрацію мозку прозапальними клітинами кровi $[1,3]$.

Таблиця 1. Кількість клітин, виділених із 10 мг тканини з різних структур мозку після черепно-мозкової травми $\left(\times 10^{7}\right)$

\begin{tabular}{|c|c|c|c|c|}
\hline \multirow{2}{*}{ Групи тварин } & \multicolumn{4}{|c|}{ Ділянка мозку } \\
\cline { 2 - 5 } & кора & гіпокамп & таламус & мозочок \\
\hline $\begin{array}{c}\text { ЧМТ, } \\
\mathrm{n}=6\end{array}$ & $49,5 \pm 0,51$ & $4,65 \pm 0,8$ & $5,41 \pm 0,59$ & $4,27 \pm 0,91$ \\
\hline $\begin{array}{c}\text { Контроль, } \\
\mathrm{n}=5\end{array}$ & $3,65 \pm 1,44$ & $3,64 \pm 0,79$ & $3,71 \pm 0,91$ & 0,152 \\
\hline $\mathrm{P}$ & 0,062 & 0,0025 & 0,0015 & \\
\hline
\end{tabular}

Водночас із збільшенням клітин у паренхімі мозку визначали підвищення продукції NO цими клітинами (табл. 2). Найдостовірнішу кількість NO синтезували клітини, виділені з гіпокампальної ділянки мозку, виявлено й підвищення продукції NO клітинами таламуса, але воно не вірогідне, порівняно з відповідними клітинами інтактних щурів $(p=0,260)$. Кількість NO, який виділявся із клітин кіркової ділянки мозку та мозочка щурів, практично не змінювалась після ЧМТ, порівняно зі здоровими тваринами контрольної групи. Отже, проведені дослідження показують особливості розвитку запалення в різних структурах та ділянках мозку, а саме, виявлено різний вміст клітин, які можна виділити методом ферментної обробки тканини головного мозку, а також установлено неоднакову продукцію NO цими клітинами в окремих ділянках мозку. При дослідженні процесів набряку мозку на 5-ту добу після ЧМТ виявили (табл. 3), що в кірковій, гіпокампальній та таламічній ділянках головного мозку вірогідно підвищений вміст води, що свідчить про наявність набряку в цих частках мозку. Незначне підвищення вмісту води виявлене і в мозочку. Отже на 5-ту добу після легкої чМТ у головному мозку зберігаються ознаки набряку мозку, який може мати різний первинний травматичний чи вторинний прозапальний механізми розвитку $[2,3,7]$.

Отже, на основі проведених нами досліджень встановлено, що кіркові та підкоркові структури головного мозку мають прояви запальної реакції, різні за інтенсивністю.

Таблиця 2. Вміст супероксиду азоту (NO) у клітинах окремих структур мозку після черепно-мозкової травми (на $1 \times 10^{7}$ клітин)

\begin{tabular}{|c|c|c|c|c|}
\hline \multirow{2}{*}{ Групи тварин } & \multicolumn{4}{|c|}{ Ділянка мозку } \\
\cline { 2 - 5 } & кора & гіпокамп & таламус & мозочок \\
\hline $\begin{array}{c}\text { ЧМТ, } \\
\mathrm{n}=5\end{array}$ & $14,32 \pm 6,9$ & $18,28 \pm 3,9$ & $16,14 \pm 2,3$ & $19,4 \pm 7,48$ \\
\hline $\begin{array}{c}\text { Контроль, } \\
\mathrm{n}=4\end{array}$ & $14,55 \pm 1,3$ & $11,85 \pm 1,9$ & $14,23 \pm 2,81$ & 0,35 \\
\hline $\mathrm{P}$ & 0,47 & 0,007 & 0,260 & 0,35 \\
\hline
\end{tabular}


Огляди літератури, оригінальні дослідження, погляд на проблему, випадок з практики, короткі повідомлення

Таблиця 3. Відсотковий вміст $\mathrm{H}_{2} \mathrm{O}$ в паренхімі різних структур головного мозку після черепно-мозкової травми (\%)

\begin{tabular}{|c|c|c|c|c|}
\hline \multirow{2}{*}{ Групи тварин } & \multicolumn{4}{|c|}{ Ділянка мозку } \\
\cline { 2 - 5 } & кора & гіпокамп & таламус & мозочок \\
\hline $\begin{array}{c}\text { чМТ, } \\
\text { n=5 }\end{array}$ & $66,25 \pm 3,09$ & $72,75 \pm 10,6$ & $69,75 \pm 9,4$ & $50,4 \pm 7,1$ \\
\hline $\begin{array}{c}\text { Контроль, } \\
\text { n=5 }\end{array}$ & $53,6 \pm 8,6$ & $57,4 \pm 7,3$ & $54,2 \pm 10,2$ & 0,17 \\
\hline $\mathrm{P}$ & 0,014 & 0,019 & 0,029 & \\
\hline
\end{tabular}

Найбільш значні ознаки запалення спостерігали у двох ділянках головного мозку - в гіпокампальній та таламічній зонах. Найменшу реакцію на ЧМТ виявив мозочок, а це може свідчити про те, що при легкій ЧМТ розвивається запалення у ділянці нанесення травми у півкулях головного мозку і воно може мати обмежений регіональний характер. У корі лобно-скроневої ділянки головного мозку, незважаючи на те, що в цій ділянці була нанесена ЧМТ, виявляли менші ознаки запалення, ніж у таламусі та гіпокампі, що можна пов'язати, по-перше, з досить пізніми термінами дослідження, а саме 5-ю добою після травми, або зі складністю міграції клітин у кіркові структури мозку та розвитком там запалення, можливо, в корі мозку швидко виникає і регресує запальна реакція, на відміну від підкіркових структур мозку, де міститься більша кількість мікрогліальних та гліальних клітин і куди легше надходять запальні клітини з крові $[1,9]$. По-друге, проведені дослідження показують, що запалення після ЧМТ може обмежуватись певними зонами або частками головного мозку [7], мозочок практично не виявляв ознак запалення після ЧМТ. По-третє, отримані результати вказують на особливості розвитку запальних реакції у певних структурах головного мозку на ЧМТ, які зберігаються і на 5-ту добу після травми, що є показанням для використання тривалого патогенетичного протизапального лікування.

Висновки. 1. Після легкої ЧМТ у щурів виникають запальні реакції в кіркових та підкіркових ділянках головного мозку, які проявляються збільшенням кількості клітин у цих зонах мозку, підвищеною продукцією оксиду азоту, та розвитком набряку мозку.

2. У гіпокампальній та таламічній ділянках мозку прояви запалення значно більші, ніж у кіркових структурах головного мозку, про що свідчить вірогідне збільшення кількості клітин, які виділяються з цих ділянок, продукції оксиду азоту та набряку мозку.

3. Ділянки мозку, які віддалені від зони нанесення травми, а саме мозочок, практично не мають проявів запалення, що вказує на те, що при легкій ЧМТ у щурів запальні реакції розвиваються в основному в півкулях головного мозку.

4. Прояви запалення на 5-ту добу після легкої ЧМТ у різних ділянках мозку свідчать про те, що ця травма супроводжується значними порушеннями, які потребують проведення відповідного лікування.

\section{ЛІТЕРАТУРА}

1. Das M. New perspectives on central and peripheral immune responses to acute traumatic brain injury / M. Das, S. Mohapatra, S. S. Mohapatra // J. Neuroinflammation. - 2012. - Vol. 9. - P. 236-247.

2. Corps K. N. Inflammation and neuroprotectionin traumatic brain injury / K. N. Corps, T. L. Roth, D. B. McGavern // JAMA Neurol. - 2015. - Vol. 72 (3). - P. 355-362.

3. Neuroinflammation in animal models of traumatic brain injury / C. Chiu, Y. Liao, J. Wang [et al.] // J. Neurosci. Methods. - 2016. - Vol. 272. - P. 38-49.

4. Лисяний М. И. Двойная роль иммунной системы в патогенезе черепномозговой травмы / М. И. Лисяний // Ukr. Neurosurg. J. - 2019. - Vol. 25 (1). - P. 5-11.
5. Современные представления о патогенезе закрытой черепно-мозговой травмы / И. Г. Васильева, А. Н. Васильев, М. Р. Костюк [и др.] ; под ред. Е. Г. Педаченко. - К. : ТОВ «Зщуга», 1996. - 282 с.

6. Bergold P. J. Treatment of traumatic brain injury with anti-inflammatorydrugs / P. J. Bergold // Exp. Neurol. -2016. - Vol. 275, Pt 3 (Pt 3). - P. 367-380.

7. Werner C. Pathophysiology of traumatic brain injury / C. Werner, K. Engelhard // Br. J. Anaesth. - 2007. Vol. 99 (1). - P. 4-9.

8. Woodcock T. The role of markers of inflammation in traumatic brain injury / T. Woodcock, M. C. MorgantiKossmann // Front. Neurol. - 2013. - Vol. 4. - P. 18-23. 
Огляди літератури, оригінальні дослідження, поглядн на

9. Challenging the role of adaptive immunity in neurotrauma: Rag1(-/-) mice lacking mature B and T cells do not show neuroprotection after closed head injury / S. Weckbach, M. Neher, J. T. Losacco [et al.] // J. Neurotrauma. - 2012. - Vol. 29 (6). - P. 1233-1242.

10. Романова Г. А. Моделирование черепно-мозговой травмы / Г. А. Романова, Ф. М. Шакова, А. Л. Парфенова // Пат. физиология и эксперим. терапия. - 2015. T. 59, № 2. - С. 112-115.

11. Бонь Е. И. Строение и развитие гиппокампа крысы / Е. И. Бонь, С. М. Зиматкин // Журнал Гродненского гос. мед. ун-та. - 2018. - Т. 16 (2). - С. 132-138.

12. Ноздрачев А. Я. Анатомия крысы. Учеб.-практ. блему, випадок з практики, короткі повідомлення руководство / А. Я. Ноздрачев, Е. Л. Поляков. - СПб., 2001. - 197 C.

13. Administration of S-nitrosoglutathione after traumatic brain injury protects the neurovascular unit and reduces secondary injury in a rat model of controlled cortical impact / M. Khan, Y. B. Im, A. Shunmugavel [et al.] // J. Neuroinflammation. - 2009. - Vol. 6. - P. 32.

14. Кіселик І. О. Особливості визначення нітратів та нітритів в периферичній крові у хворих на вірусні гепатити, та при синдромі жовтяниці іншої етіології / І. О. Кіселик, М. Д. Луцик, Л. Ю. Шевченко // Лабораторна діагностика. - 2001. - № 3. - С. 43-45.

\section{REFERENCES}

1. Das, M., Mohapatra, S., \& Mohapatra, S.S. (2012). New perspectives on central and peripheral immune responses to acute traumatic brain injury. J. Neuroinflammation, 9, 236-247.

2. Corps, K.N., Roth, T.L., \& McGavern, D.B. (2015). Inflammation and neuroprotectionin traumatic brain injuгу. JAMA Neurol., 72 (3), 355-362.

3. Chiu, C., Liao, Y., Wang, J., Tweedie, D., Karnati, H., Greig, N., \& Wang, J. (2016). Neuroinflammation in animal models of traumatic brain injury. J. Neurosci. Methods, 272, 38-49. DOI: 10.1016/j.jneumeth.2016.06.018

4. Lisyaniy, M.I. (2019). Dvoynaya rol immunnoy sistemy $v$ patogeneze cherepnomozgovoy travmy [Dual role of the immune system in the pathogenesis of traumatic brain injury]. Ukr. Neurosurg. J., 25 (1), 5-11 [ in Russian].

5. Vasilyeva, I.G., Vasilyev, A.N., Kostyuk, M.R., Kurako, Yu.L., Lisyanyy, N.I., Nosov, A.T., \& Chopik, N.G. (1996). Sovremennyye predstavleniya o patogeneze zakrytoy cherepno-mozgovoy travmy [Modern ideas about the pathogenesis of closed craniocerebral trauma]. Kyiv: TOV «Zshchuga» [in Russian].

6. Bergold, P.J. (2016). Treatment of traumatic brain injury with anti-inflammatorydrugs. Exp. Neurol., 275, 3 (3), 367-380.

7. Werner, C., \& Engelhard, K. (2007). Pathophysiology of traumatic brain injury. Br. J. Anaesth., 99 (1), 4-9. DOI: 10.1093/bja/aem131.

8. Woodcock, T., \& Morganti-Kossmann, M.C. (2013). The role of markers of inflammation in traumatic brain injury. Front. Neurol., 4, 18-23.

9. Weckbach, S., Neher, M., Losacco, J.T., Bolden, A.L., Kulik, L., Flierl, M.A., \& Stahel, P.F. (2012). Challenging the role of adaptive immunity in neurotrauma: Rag1(-/-) mice lacking mature $B$ and $T$ cells do not show neuroprotection after closed head injury. J. Neurotrauma, 29 (6), 1233-1242. DOI: 10.1089/neu.2011.2169

10. Romanova, G.A., Shakova, F.M., \& Parfenova, A.L. (2015). Modelirovaniye cherepno-mozgovoy travmy [Simulation of traumatic brain injury]. Pat. fiziologiya i esperim. terapiya - Patol. Physiol. Exp. Ther., 59 (2), 112-115 [in Russian].

11. Bon, Ye.I., \& Zimatkin, S.M. (2018). Stroyeniye i razvitiye gippokampa krysy [Structure and development of hippocampa rat]. Zhurnal Grodnenskogo gosudarstvennogo meditsinskogo universiteta - Journal of Grodno State Medical University, 16 (2), 132-138. DOI: 10.25298/22218785-2018-16-2-132-138 [in Russian].

12. Nozdrachev, A.Ya., \& Polyakov, Ye.L. (2001). Anatomiya krysy. Uch.-prakt. rukovodstvo [Rat anatomy. Educ. Pract. Guide]. Saint-Petersburg [in Russian].

13. Khan, M., Im, Y.-B., Shunmugavel, A., Gilg, A.G., Dhindsa, R.K., Singh, A.K., \& Singh, I. (2009). Administration of S-nitrosoglutathione after traumatic brain injury protects the neurovascular unit and reduces secondary injury in a rat model of controlled cortical impact. J. Neuroinflammation, 6, 32. DOI: 10.1186/1742-2094-6-32

14. Kiselyk, I.O., Lutsyk, M.D., \& Shevchenko, L.Yu. (2001). Osoblyvosti vyznachennia nitrativ ta nitrytiv v peryferichnii krovi u khvorykh na virusni hepatyty, ta pry syndromi zhovtianytsi inshoi etiolohii [Features of determination of nitrates and nitrites in peripheral blood in patients with viral hepatitis and jaundice syndrome of other etiology]. Laboratorna diahnostyka - Laboratory Diagnostics, 3, 43-45 [in Russian]. 
Огляди літератури, оригінальні дослідження, погляд на проблему, випадок з практики, короткі повідомлення ОСОБЕННОСТИ РАЗВИТИЯ ВОСПАЛИТЕЛЬНЫХ РЕАКЦИЙ В КОРКОВЫХ И ПОДКОРКОВЫХ ОТДЕЛАХ ГОЛОВНОГО МОЗГА КРЫС ПОСЛЕ ЛЕГКОЙ ЧЕРЕПНО-МОЗГОВОЙ ТРАВМЫ

\author{
๑М. И. Лисяный, А. В. Паламарьова, А. А. Лисяный

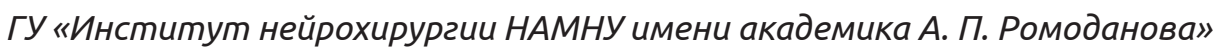

РЕзЮМЕ. Черепно-мозговая травма (ЧМТ) характеризуется целым рядом патологических реакций в паренхиме мозга, которые зависят от тяжести травмы и имеют длительное течение, что может приводить к развитию неврологических нарушений и инвалидности, среди которых важную роль играют воспалительные процессы, которые реализуются как микроглиальными, так и глиально-макрофагальными клетками головного мозга, и с помощью нейтрофилов, моноцитов и лимфоцитов крови. В то же время, еще недостаточно изучено развитие этих патологических аутоиммунных реакций в отдельных важных структурах головного мозга.

Цель - изучение особенностей состояния воспаления на 5-е сутки после легкой чМТ у крыс, а именно, определение количества и активности провоспалительных клеток и уровня отека в корковой, гипокампальной и таламической областях мозга.

Материал и методы. В работе использованы экспериментальные животные, половозрелые крысы разного пола весом 120-160 г (разведение вивария ГУ «ИНХ АМН»). Все работы с экспериментальными животными проводили с соблюдением законодательных норм и требований Закона Украины № 3447 IV «О защите животных от жестокого обращения», «Европейской конвенции о защите позвоночных животных, используемых для исследовательских и других научных целей» (Страсбург, 1986), с учетом принципов биоэтики и норм биологической безопасности. Животных содержали в стандартных условиях аккредитованного вивария, эвтаназию проводили под эфирным наркозом. Черепно-мозговую травму у крыс моделировали согласно рекомендациям Романова Г. А. и др. (2015) путем падения груза (весом 100 г) с высоты 120 см на голову наркотизированных крыс. Получение клеток головного мозга крыс из определенных долей мозга проводили методом ферментной диссоциации 0,4 \% раствором трипсина. Оксид азота определяли при помощи реактива Грисса. Отек определенных структур мозга определяли по содержанию воды в ткани мозга до и после 48-часового высушивания.

Результаты. После легкой ЧМТ у крыс возникают воспалительные реакции в корковых и подкорковых областях головного мозга, которые проявляются на 5-е сутки после травмы увеличением количества провоспалительных клеток в исследуемых долях мозга, повышенной продукцией оксида азота и развитием отека мозга. В гипокампальной и таламической областях мозга проявления воспаления были значительно большими, чем в корковых структурах головного мозга.

Вывод. Проявления воспаления на 5-е сутки после легкой чМТ в различных областях мозга указывают на то, что эта травма сопровождается значительными нарушениями, которые требуют проведения соответствующего лечения.

КЛЮЧЕВЫЕ СЛОВА: черепно-мозговая травма; крысы; воспаление; отек мозга; оксид азота.

\title{
PECULIARITIES OF DEVELOPMENT OF INFLAMMATORY REACTIONS IN CORE AND SUBCORTAL DEPARTMENTS OF RAT'S BRAIN AFTER LIGHT BRAIN INJURYRY
}

\author{
@N. I. Lisyany, A. V. Palamaryova, A. O. Lisyany \\ A. Romodanov Neurosurgery Institute National Academy of Medical Sciences of Ukraine
}

SUMMARY. Traumatic brain injury (TBI) is characterized by a number of pathological reactions in the brain parenchyma, which depend on the severity of the injury and have a long course, which can lead to the development of neurological disorders and disability, among which inflammatory processes play an important role, which are realized as microglial and glial-macrophage cells of the brain, and with the help of neutrophils, monocytes and blood lymphocytes. At the same time, the development of these pathological autoimmune reactions in certain important structures of the brain has not yet been sufficiently studied.

The aim - to study the features of the state of inflammation on the 5th day after mild TBI in rats, namely, to determine the number and activity of pro-inflammatory cells and the level of edema in the cork, hypocampal and thalamic regions of the brain.

Material and Methods. Experimental animals, sexually mature rats, of different sex weighing $120-160 \mathrm{~g}$ (breeding of the vivarium of the State Institution "INKh AMN") were used in the work. All work with experimental animals was carried out in compliance with the legislative norms and requirements of the Law of Ukraine No. 3447 IV "On the Protection of Animals from Cruelty", "The European Convention for the Protection of Vertebrate Animals Used for Research and Other Scientific Purposes" (Strasbourg, 1986), taking into account principles of bioethics and biological safety standards. The animals were kept under standard conditions of an accredited vivarium; euthanasia was performed under ether anesthesia. Traumatic brain injury in rats was modeled according to the recommendations of Romanov G. A. et al. 
Огляди літератури, оригінальні дослідження, погляд на проблему, випадок з практики, короткі повідомлення (2015) by dropping a load (weighing $100 \mathrm{~g}$ ) from a height of $120 \mathrm{~cm}$ onto the head of anesthetized rats. The preparation of rat brain cells with certain brain lobes was carried out by the method of enzymatic dissociation with a $0.4 \%$ trypsin solution. Nitric oxide was determined using the Griss reagent. Edema of certain brain structures was determined by the water content in the brain tissue before and after 48 hours of drying.

Results. After mild TBI, rats develop inflammatory reactions in the cortical and subcortical regions of the brain, which are manifested on the 5th day after injury by an increase in the number of pro-inflammatory cells in the studied brain lobes, increased production of nitric oxide, and the development of cerebral edema. In the hypocampal and thalamic regions of the brain, the manifestations of inflammation are much greater than in the cortical structures of the brain.

Conclusion. The manifestations of inflammation on the 5th day after a mild TBI in various areas of the brain indicates that this injury is accompanied by significant disorders that require appropriate treatment.

KEY WORDS: traumatic brain injury; rats; inflammation; cerebral edema; nitric oxide.

Отримано 12.02.2021 